\title{
SERVICE-LEARNING DALAM PENDIDIKAN ARSITEKTUR: MOMEN KRITIS DALAM SUATU REFLEKSI
}

\author{
Sylviana Putri Sunario Soegondo ${ }^{1}$, Lilianny S. Arifin ${ }^{2}$ \\ 1,2. Prodi Arsitektur, Fakultas Teknik Sipil dan Perencanaan, Universitas Kristen Petra, \\ Jl. Siwalankerto 121-131, Surabaya \\ Email: sylviana@petra.ac.id
}

\begin{abstract}
Abstrak
Selama bertahun-tahun, metode pembelajaran service-learning (pembelajaran berbasis layanan yang biasa kita sebut KKN) dipercaya sebagai metode yang tepat dalam pendidikan pengalaman karena berfokus pada inisiatif yang dapat mengubah kesejahteraan sosial individu dan komitmen siswa terhadap kesejahteraan masyarakat secara umum. Belajar memerlukan transformasi, baik secara individual maupun dari pengalaman dunia sosial melalui refleksi. Geleta dan Gilliam (2003) mengatakan bahwa refleksi adalah elemen kunci yang menghubungkan pengalaman pelayanan melalui cara yang bermakna dengan pikiran, sensasi dan nilai-nilai pribadi siswa. Ada empat elemen kunci untuk mendukung strategi efektif untuk refleksi yang bermakna: kesinambungan dan konektivitas dalam proses yang reflektif pada pengalaman belajar dan tujuan pembelajaran, tingkat pemikiran yang lebih tinggi, kepercayaan dan saling menghormati, dan refleksi kontekstual. Makalah ini mengeksplorasi implikasi refleksi kontekstual tentang momen kritis ketika pengalaman individu dibagikan dan menjadi pengetahuan implisit. Refleksi jurnal dari mahasiswa arsitektur semester 5 dikategorikan menggunakan metode analisis konten untuk menemukan pengalaman individu sebelum dan setelah melakukan proyek yang dapat dipahami sebagai pengetahuan implisit untuk menjadi pengetahuan eksplisit yang meningkatkan pengembangan karakter sebagai mahasiswa arsitektur.
\end{abstract}

Kata kunci: service- learning, pedagogi, refleksi.

\begin{abstract}
Title: Service-Learning in Architecture Education: A Critical Moment in A Reflection

For over the years, service-learning pedagogy is understood as an appropriate method in experiential education because it focuses on initiatives that has the capacity to change the social well-being of individuals and students' commitment to society's general well-being. Learning entails transformation both individually and from the social work experience through reflection. Geleta and Gilliam (2003) said that reflection is a critical element that connect the service experience in meaningful ways with students' thoughts, sensations, and values. There are four key elements to support practical strategies for meaningful reflection: continuity and connectivity in reflective process on the learning experience and objectives, higher-level thinking, atmosphere of trust and mutual respect, and contextual reflection. This paper explores the implications of contextual reflection about critical moment when an individual experience is shared and become tacit knowledge. The journal reflection from architecture students 5th semester was categorized using content analysis methods to find a personal experience before and after doing a project that can be grasped as tacit knowledge to become explicit knowledge that enhances character development as an architecture student.
\end{abstract}

Keywords: service-learning, pedagogy, reflections. 


\section{Pendahuluan}

Metode pembelajaran service-learning (pembelajaran berbasis layanan yang biasa kita sebut KKN) telah menjadi metode yang tepat untuk pendidikan pengalaman selama beberapa tahun ini, karena berfokus pada inisiatif yang dapat mengubah kesejahteraan sosial individu dan komitmen siswa untuk manfaat sosial secara keseluruhan. Belajar pada dasarnya mengubah pengalaman melalui refleksi baik secara individu maupun dari lingkungan sosial karena "Pengalaman menjadi hal yang edukatif ketika reflektif pemikiran kritis menciptakan makna baru dan mengarah pada pertumbuhan dan kemampuan untuk mengambil tindakan yang telah diinformasikan", sebagaimana dinyatakan oleh Bringle dan Hatcher (1999). Selain itu, Dewey (1938) dan Kolb (2015) menganut pandangan holistik tentang pembelajaran sebagai proses yang bertahan lama melalui perubahan pengalaman dimana pengetahuan itu diciptakan. Mereka mengakui, lebih jauh lagi, bahwa tidak semua pengalaman itu benar atau mendidik.

Refleksi bertindak sebagai jembatan antara pengalaman konseptual dan pengalaman yang spesifik. Dalam skema Dewey, pemikiran reflektif dan praktik sosial berfungsi sebagai dasar untuk latihan KKN yang lebih modern, dan refleksi memiliki peran sebagai penghubung yang diperlukan antara pengalaman dan teori. Bersama dengan Dewey, Geleta dan Gilliam (2003) mengatakan bahwa refleksi adalah elemen kunci yang menghubungkan pengalaman dalam pelayanan dengan cara yang bermakna dengan pikiran, sensasi dan nilai pribadi siswa. Ada empat elemen kunci untuk mendukung strategi efektif untuk refleksi yang bermakna: kesinambungan dan konektivitas dalam proses reflektif pada pengalaman belajar dan tujuan pembelajaran, tingkat pemikiran yang lebih tinggi, kepercayaan dan saling menghormati, dan refleksi kontekstual. Aspek-aspek faktual ini mengarah pada pemikiran kritis tentang apa maksud dari refleksi pada pendidikan service-learning atau dalam praktiknya kita sebut KKN di bidang arsitektur. Makalah ini mengeksplorasi keterlibatan refleksi kontekstual tentang momen kritis ketika pengalaman individu dibagikan dan menjadi pengetahuan implisit.

\section{Metode}

Studi tentang momen kritis dan hubungannya dengan empat aspek refleksi oleh Geleta dan Gilliam (2003) dilakukan untuk memahami pentingnya berbagi pengalaman dalam refleksi untuk memahami penjelasan yang lebih obyektif. Kemudian, refleksi jurnal dari mahasiswa arsitektur semester 5 dikategorikan menggunakan metode analisis isi menurut empat aspek dalam penelitian Geleta dan Gilliam (2003): kesinambungan dan konektivitas dalam proses reflektif pada pengalaman belajar dan tujuan pembelajaran, tingkat pemikiran yang lebih tinggi, kepercayaan dan saling menghormati, dan refleksi kontekstual yang ditafsirkan kembali oleh penulis menjadi aspek pembelajaran yang diperoleh, berpikir kritis, rasa hormat dan koneksi, dan perasaan emosional (Tabel 1) untuk menemukan pengalaman individu sebelum dan setelah melakukan proyek yang dapat dipahami sebagai pengetahuan implisit untuk diubah menjadi pengetahuan eksplisit yang dapat meningkatkan pengembangan karakter sebagai mahasiswa arsitektur. 
Dua puluh lima refleksi mahasiswa telah dianalisis dan disajikan dalam tabel 1 berikut.

Tabel 1. Penafsiran ulang dari empat aspek dalam refleksi yang telah disiapkan oleh penulis

\begin{tabular}{|l|l|l|}
\hline Poin & \multicolumn{1}{|c|}{$\begin{array}{c}\text { Empat Aspek } \\
\text { Refleksi }\end{array}$} & \multicolumn{1}{|c|}{ Makna } \\
\hline 1. & $\begin{array}{l}\text { Kesinambungan } \\
\text { dan konektivitas } \\
\text { dalam proses } \\
\text { reflektif pada } \\
\text { pengalaman belajar } \\
\text { dan tujuan } \\
\text { pembelajaran }\end{array}$ & $\begin{array}{l}\text { Aspek } \\
\text { pembelajaran } \\
\text { telah } \\
\text { didapatkan }\end{array}$ \\
\hline 2. & $\begin{array}{l}\text { Tingkat pemikiran } \\
\text { yang lebih tinggi }\end{array}$ & Berpikir kritis \\
\hline 3. & $\begin{array}{l}\text { Kepercayaan dan } \\
\text { saling mengormati }\end{array}$ & $\begin{array}{l}\text { Rasa hormat } \\
\text { dan koneksi }\end{array}$ \\
\hline 4. & Releksi kontekstual & $\begin{array}{l}\text { Perasaan } \\
\text { emosional }\end{array}$ \\
\hline
\end{tabular}

Sumber: Geleta \& Gilliam, 2003 dan penafsiran penulis, 2020

\section{Hasil dan Pembahasan}

Menurut sebuah studi tentang metodologi refleksi momen kritis, metode untuk melihat kembali dan mengambil pelajaran dari suatu pengalaman oleh Center for Reflective Community Practice - MIT, momen kritis adalah 'titik balik' ketika situasi atau emosi menjadi lebih buruk atau lebih baik. Harus ada perspektif individu tentang masa kritis, mengubah waktu dari satu pandangan. Selain itu, sebagai pengetahuan, saat-saat kritis telah dibagi menjadi pengetahuan eksplisit dan tacit. Pengetahuan eksplisit adalah aspek pembelajaran itu sendiri, sedangkan tacit atau yang bisa dipahami tanpa dikatakan adalah tingkat penyebabnya.

Geleta dan Gilliam (2003) telah menjelaskan bahwa ada empat aspek penting dalam refleksi, yaitu kontinuitas dan konektivitas dalam proses reflektif pada pengalaman belajar dan tujuan pembelajaran, tingkat pemikiran yang lebih tinggi, kepercayaan dan saling menghormati, dan refleksi kontekstual. Dalam riset mereka, penulis berupaya meyakinkan bahwa ekspresi dalam refleksi bukanlah masalah pengetahuan eksplisit, tetapi latar belakang di baliknya justru lebih penting. Misalnya, memiliki ekspresi kebahagiaan yang sama. Satu orang merasa bahagia karena kondisi sosial yang terbuka, tetapi yang lain merasa senang karena merasa bermanfaat. Refleksi pribadi yang mungkin meliputi: Apa yang saya rasakan? Mengapa saya bereaksi seperti ini? Bagaimana saya bisa bereaksi secara berbeda selanjutnya? Apa yang saya temukan tentang diri saya yang belum saya ketahui sebelumnya? Tanpa refleksi, siswa hanya perlu mengikuti gerakan melayani [dan] secara kognitif tidak terpengaruh oleh pengalaman itu (Heffernan, 2001, hal. 2-7, 9).

Selanjutnya, melalui penelitian Emosi dan Pembelajaran: Merasakan Jalan Kita Menuju Teori Baru dalam Refleksi pada Pembelajaran Berbasis Layanan (Service Learning) oleh Felten, P. , Gilchrist, L.Z., Darby, A. (2006) penulis memperoleh keyakinan bahwa meskipun emosi diberikan posisi yang menonjol dalam refleksi, seperti yang ditunjukkan oleh kutipan di atas, hal itu dibingkai sebagai 'ranah pribadi' dan digunakan terutama untuk mendorong tujuan kognitif yang lebih besar. Singkatnya, teori praktis tentang pelayanan mencerminkan dasar-dasar teoritis dari service-learning (pembelajaran berbasis layanan atau $\mathrm{KKN})$ dengan sedikit memberi perhatian pada peran yang dapat dimainkan emosi dalam refleksi pembelajaran. 


\section{Ringkasan Refleksi}

Tabel 2. Ringkasan refleksi dikategorikan ke dalam empat kata kunci

\begin{tabular}{|c|c|c|c|c|c|}
\hline \multirow[b]{2}{*}{ 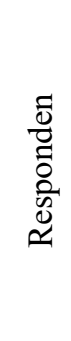 } & \multirow[t]{2}{*}{ Pernyataan } & \multicolumn{4}{|c|}{ Kata Kunci } \\
\hline & & $\begin{array}{c}\text { Poin } 1 \\
\text { Aspek } \\
\text { Belajar } \\
\text { yang } \\
\text { Didapat }\end{array}$ & $\begin{array}{l}\text { Poin } 2 \\
\text { Berpikir } \\
\text { Kritis }\end{array}$ & $\begin{array}{c}\text { Poin } 3 \\
\text { Rasa Hormat } \\
\text { dan Koneksi }\end{array}$ & $\begin{array}{l}\text { Poin } 4 \\
\text { Perasaan } \\
\text { Emosional }\end{array}$ \\
\hline \multirow[t]{2}{*}{1.} & 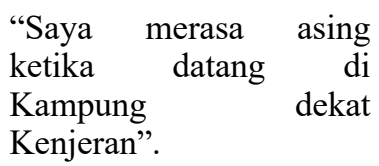 & & & & Asing \\
\hline & $\begin{array}{l}\text { "Partner kelompok kita } \\
\text { sudah membimbing kita } \\
\text { dengan tanggung jawab" }\end{array}$ & & & $\begin{array}{l}\text { Panduan dari } \\
\text { HABITAT }\end{array}$ & \\
\hline \multirow[t]{3}{*}{2.} & $\begin{array}{l}\text { "Saya } \\
\text { bersemangat } \\
\text { penasaran sekaligus } \\
\text { lingkungan yang akan } \\
\text { saya desain ulang" }\end{array}$ & $\begin{array}{l}\text { Rasa } \\
\text { penasaran }\end{array}$ & & & \\
\hline & $\begin{array}{l}\text { "Saya sangat tergerak } \\
\text { untuk mendesain rumah } \\
\text { yang lebih baik dan bisa } \\
\text { memenuhi kebutuhan } \\
\text { keluarga pak K" }\end{array}$ & & $\begin{array}{l}\text { Tergerak } \\
\text { oleh } \\
\text { rumah } \\
\text { yang } \\
\text { sangat } \\
\text { kecil }\end{array}$ & & \\
\hline & $\begin{array}{l}\text { "Saya melihat keluarga } \\
\text { pak K } \\
\text { menyenangkan. } \\
\text { Walaupun tinggal di } \\
\text { dalam keadaan rumah } \\
\text { yang demikian, keluarga } \\
\text { mereka tetap bisa } \\
\text { berkarya dan merasa } \\
\text { nyaman dengan kondisi } \\
\text { seperti itu. Lukisan yang } \\
\text { ada di dinding-dinding } \\
\text { rumah menggambarkan } \\
\text { keluarga pak K yang } \\
\text { tetap bersyukur atas } \\
\text { rumah tinggal yang } \\
\text { mereka tempati" }\end{array}$ & & & $\begin{array}{l}\text { Belajar } \\
\text { berterima } \\
\text { kasih }\end{array}$ & Bahagia \\
\hline 3. & $\begin{array}{l}\text { "Saya rasakan saat } \\
\text { survey ke lapangan } \\
\text { adalah perasaan tidak } \\
\text { nyaman saat masuk ke } \\
\text { rumah warga" }\end{array}$ & & & & $\begin{array}{l}\text { Tidak } \\
\text { nyaman: } \\
\text { Claustrofobia }\end{array}$ \\
\hline
\end{tabular}




\begin{tabular}{|c|c|c|c|c|}
\hline \multicolumn{2}{|c|}{4.} & & & \\
\hline \multirow[t]{2}{*}{5.} & $\begin{array}{l}\text { "Saya rasakan sangat } \\
\text { senang. Karena saya bisa } \\
\text { berkunjung ke tempat } \\
\text { yang belum pernah saya } \\
\text { kunjungi" }\end{array}$ & & & Bahagia \\
\hline & $\begin{array}{l}\text { "Ternyata di sana pun Ibu } \\
\text { Subiya sangat ramah } \\
\text { dengan kami. Ia senang } \\
\text { bercanda dan sangat } \\
\text { welcome. Selain itu, saya } \\
\text { merasa senang karena } \\
\text { dapat membantu sesama } \\
\text { yang kurang beruntung. } \\
\text { Saya juga senang karena } \\
\text { bisa ikut merasakan apa } \\
\text { yang dirasakan oleh Ibu } \\
\text { Subiya dan juga dapat } \\
\text { membantu Ibu Subiya } \\
\text { untuk mewujudkan } \\
\text { keinginannya (semoga) } \\
\text { yang memiliki kamar } \\
\text { yang nyaman dan bebas } \\
\text { tikus dan kucing" }\end{array}$ & $\begin{array}{l}\text { Dapat } \\
\text { membantu } \\
\text { sesama }\end{array}$ & $\begin{array}{l}\text { Bersenda } \\
\text { gurau }\end{array}$ & \\
\hline \multirow[t]{3}{*}{6.} & $\begin{array}{lr}\text { "Saya cukup antusias } \\
\text { dengan kondisi yang ada, } \\
\text { saya penasaran } \\
\text { bagaimana keadaan } \\
\text { rumah yang akan } \\
\text { diperbaiki" }\end{array}$ & & & $\begin{array}{l}\text { Antusias; } \\
\text { ingin tahu }\end{array}$ \\
\hline & $\begin{array}{l}\text { "Untungnya ada bantuan } \\
\text { Pak Agus, pembimbing } \\
\text { kami dari HABITAT } \\
\text { sehingga pembicaraan } \\
\text { dan wawancaranya bisa } \\
\text { dimulai dengan baik" }\end{array}$ & & $\begin{array}{l}\text { HABITAT } \\
\text { Membantu } \\
\text { proses } \\
\text { wawancara }\end{array}$ & \\
\hline & $\begin{array}{l}\text { "Hal lain yang saya } \\
\text { pikirkan adalah betapa } \\
\text { beruntungnya saya hidup } \\
\text { dengan segala yang } \\
\text { sudah ada, hidup jauh } \\
\text { lebih beruntung, tetapi } \\
\text { melihat Ibu Suraiyah } \\
\text { dengan keluarganya yang } \\
\text { terus berjuang dan selalu } \\
\text { bersyukur" }\end{array}$ & Bersyukur & & \\
\hline 7. & $\begin{array}{l}\text { "Saya merasa sangat } \\
\text { bersemangat dan } \\
\text { memiliki rasa ingin tahu } \\
\text { yang tinggi untuk } \\
\text { mengetahui keadaan di } \\
\text { perkampungan" }\end{array}$ & & & Antusias \\
\hline 8. & "Saya cukup semangat & & & Antusias \\
\hline
\end{tabular}




\begin{tabular}{|c|c|c|c|c|}
\hline & $\begin{array}{l}\text { mengingat site yang akan } \\
\text { dikunjungi berlokasi di } \\
\text { dekat pantai" }\end{array}$ & & & \\
\hline & $\begin{array}{l}\text { "Setelah melihat kondisi } \\
\text { rumah Pak Karyawanto, } \\
\text { saya merasa iba karena } \\
\text { menurut saya rumah } \\
\text { tersebut tidak layak untuk } \\
\text { dihuni. Apalagi setelah } \\
\text { saya mengetahui bahwa } \\
\text { penghuni dari rumah } \\
\text { tersebut } 7 \text { orang, saya } \\
\text { tidak dapat } \\
\text { membayangkan betapa } \\
\text { sesaknya ruang di dalam. } \\
\text { Kondisi rumah begitu } \\
\text { berantakan, sempit, dan } \\
\text { gelap" }\end{array}$ & & $\begin{array}{l}\text { Perasaan } \\
\text { iba }\end{array}$ & \\
\hline \multirow[t]{2}{*}{9.} & $\begin{array}{l}\text { "Saya merasa rumah itu } \\
\text { sangat kecil dan tidak } \\
\text { ditata dengan rapi karena } \\
\text { pada bagian pintu } \\
\text { terdapat perabot yang } \\
\text { sangat menghambat } \\
\text { sirkulasi dan ternyata } \\
\text { yang pertama kali saya } \\
\text { pikir Ibu Husna tinggal } \\
\text { bertiga ternyata memiliki } \\
\text { enam anggota keluarga } \\
\text { yang tinggal bersama di } \\
\text { sana" }\end{array}$ & & Sempit & \\
\hline & $\begin{array}{l}\text { "Saat itu saya cukup } \\
\text { terkejut karena rumah } \\
\text { dengan ukuran } 4 \text { x } 10 \text { itu } \\
\text { hanya memiliki } 3 \text { kamar } \\
\text { tidur. Saat itu saya cukup } \\
\text { bersyukur bahwa saya } \\
\text { tinggal di rumah yang } \\
\text { berkecukupan" }\end{array}$ & Bersyukur & & Terkejut \\
\hline 10. & $\begin{array}{l}\text { "Ketika saya berkunjung } \\
\text { untuk melakukan survey } \\
\text { ke lapangan, saya sangat } \\
\text { senang karena pertama } \\
\text { kali sampai di rumah Bu } \\
\text { Subiya, sudah disambut } \\
\text { dengan baik dan ramah } \\
\text { oleh pemillik rumah. } \\
\text { Namun, saya merasa } \\
\text { prihatin karena tempat } \\
\text { tinggalnya yang kecil, } \\
\text { sempit dan bisa dikatakan } \\
\text { jauh dari kata layak, di } \\
\text { sisi lain saat } \\
\text { mewawancarai Bu } \\
\text { Subiya, banyak } \\
\text { pelajaran-pelajaran yang }\end{array}$ & Bersyukur & Sempit & Bahagia \\
\hline
\end{tabular}




\begin{tabular}{|c|c|c|c|c|c|}
\hline & $\begin{array}{l}\text { bisa saya dapatkan dari } \\
\text { Bu Subiya, beliau yang } \\
\text { begitu kuat dan tegar, } \\
\text { mengajarkan saya untuk } \\
\text { selalu bersyukur apapun } \\
\text { yang terjadi pada hidup } \\
\text { saya" }\end{array}$ & & & & \\
\hline \multirow[t]{3}{*}{11.} & $\begin{array}{l}\text { "Saya cukup merasa } \\
\text { terkejut karena rumah } \\
\text { yang saya dapatkan } \\
\text { hanya memiliki lebar } \\
\text { bangunan sebesar 3m" }\end{array}$ & & & & Terkejut \\
\hline & $\begin{array}{l}\text { "Saya merasa sangat } \\
\text { panas di dalamnya karena } \\
\text { tidak ada cross } \\
\text { ventilation dan rumah } \\
\text { terasa sangat sesak" }\end{array}$ & & Pengap & & \\
\hline & $\begin{array}{lr}\text { "Saya cukup senang } \\
\text { karena saya } & \text { bisa } \\
\text { berproses bersama dosen } \\
\text { dan HABITAT" }\end{array}$ & & & $\begin{array}{l}\text { Berproses } \\
\text { bersama }\end{array}$ & \\
\hline 12. & $\begin{array}{lrr}\text { "Saya cukup } & \text { senang } \\
\text { karena } & \text { saya } & \text { bisa } \\
\text { berproses bersama dosen } \\
\text { dan HABITAT" }\end{array}$ & & & & Terkejut \\
\hline \multirow[t]{2}{*}{13.} & $\begin{array}{l}\text { "Gang kecil membuat } \\
\text { suasana menjadi sesak } \\
\text { dan kurang nyaman" }\end{array}$ & & Sempit & & \\
\hline & $\begin{array}{l}\text { "Tidak hanya toilet saja, } \\
\text { tetapi kondisi lain seperti } \\
\text { atap, dinding, lantai, } \\
\text { plafon, besaran ruang, } \\
\text { sirkulasi udara semua } \\
\text { dalam kondisi buruk. } \\
\text { Bahkan ada } 1 \text { ruang } \\
\text { kamar tidur di bagian } \\
\text { belakang tidak mendapat } \\
\text { pencahayaan dan } \\
\text { sirkulasi udara yang baik } \\
\text { sehingga di dalam kamar } \\
\text { terasa pengap, gelap dan } \\
\text { bau. Di situ saya merasa } \\
\text { bersyukur atas apa yang } \\
\text { saya miliki sekarang } \\
\text { karena ternyata masih } \\
\text { banyak orang diluar sana } \\
\text { yang harus hidup dalam } \\
\text { kondisi yang tidak layak" }\end{array}$ & $\begin{array}{l}\text { Menambah } \\
\text { penglaman; } \\
\text { bersyukur }\end{array}$ & $\begin{array}{l}\text { Pengap; } \\
\text { tidak } \\
\text { cukup } \\
\text { cahaya } \\
\text { dan udara } \\
\text { segar }\end{array}$ & & \\
\hline 14. & $\begin{array}{l}\text { "Merasa prihatin dengan } \\
\text { kondisi rumah Bu Subiya } \\
\text { yang lembab dan kurang } \\
\text { pencahayaan. Saya } \\
\text { merasa ini adalah sebuah }\end{array}$ & $\begin{array}{l}\text { Pengalaman } \\
\text { yang } \\
\text { berbeda }\end{array}$ & $\begin{array}{l}\text { Pengap; } \\
\text { merasa } \\
\text { iba }\end{array}$ & & \\
\hline
\end{tabular}




\begin{tabular}{|c|c|c|c|c|}
\hline & $\begin{array}{l}\text { pengalaman berbeda dan } \\
\text { seru" }\end{array}$ & & & \\
\hline & $\begin{array}{l}\text { "Membuat saya takjub } \\
\text { bahwa ada juga tempat } \\
\text { seperti ini di Surabaya" }\end{array}$ & & & Takjub \\
\hline 15. & $\begin{array}{l}\text { "Saya excited karena } \\
\text { saya punya ketertarikan } \\
\text { untuk } \\
\text { kampung" mempelajari }\end{array}$ & & & Bersemangat \\
\hline \multirow[t]{2}{*}{16.} & $\begin{array}{lr}\text { "Awalnya } & \text { saya } \\
\text { bersemangat } & \text { untuk } \\
\text { mengikuti } & \text { survey } \\
\text { langsung ke perumahan } \\
\text { penduduk, } \\
\text { ternyata apa yamun } \\
\text { dibayangkan tidak seperti } \\
\text { aslinya. Saya tidak } \\
\text { menyangka ternyata yang } \\
\text { harus didesain adalah } \\
\text { rumah yang terbilang } \\
\text { tidak layak huni untuk } \\
\text { ditinggali, dengan luas } \\
\text { lahan yang sangat kecil } \\
\text { dan sirkulasi udara } \\
\text { kurang baik" }\end{array}$ & & $\begin{array}{l}\text { Sempit; } \\
\text { jeleknya } \\
\text { sistem } \\
\text { sirkulasi } \\
\text { udara }\end{array}$ & Antusias \\
\hline & $\begin{array}{l}\text { "Saya merasa sangat } \\
\text { kelelahan dan tidak } \\
\text { menyangka dengan } \\
\text { survey seperti itu ternyata } \\
\text { cukup melelahkan dan } \\
\text { menguras tenaga, tetapi } \\
\text { dari survey saya } \\
\text { mendapat banyak hal } \\
\text { baru yang belum pernah } \\
\text { saya dapat sebelumnya" }\end{array}$ & $\begin{array}{l}\text { Menambah } \\
\text { pengalaman }\end{array}$ & & Kelelahan \\
\hline \multirow[t]{2}{*}{17.} & $\begin{array}{lr}\text { "Saya merasa sangat } \\
\text { terhormat, beruntung dan } \\
\text { bersyukur } & \text { karena } \\
\text { menurut saya } & \text { tidak } \\
\text { semua orang dapat } \\
\text { mengalami hal yang } \\
\text { sama" }\end{array}$ & Bersyukur & & $\begin{array}{l}\text { Merasa } \\
\text { beruntung }\end{array}$ \\
\hline & $\begin{array}{l}\text { "Saya tidak pernah } \\
\text { melihat apa yang saya } \\
\text { lihat dirumah Bu H. } \\
\text { Namun memang rasa jijik } \\
\text { dan kotor sempat terpikir } \\
\text { di dalam pikiran saya } \\
\text { karena rumah Bu H } \\
\text { sangat tidak tertata } \\
\text { dengan baik" }\end{array}$ & & Kotor & \\
\hline 18. & $\begin{array}{l}\text { "Saat sesampai di } \\
\text { adalah pana } \\
\text { panas }\end{array}$ & & Panas & \\
\hline
\end{tabular}




\begin{tabular}{|c|c|c|c|c|}
\hline & $\begin{array}{l}\text { bangunan warga pun } \\
\text { cukup sempit" }\end{array}$ & & & \\
\hline & $\begin{array}{l}\text { "Warga yang saya lewati } \\
\text { pada komplek tersebut } \\
\text { sangatlah ramah" }\end{array}$ & & & Ramah \\
\hline 19. & $\begin{array}{l}\text { "Saya cukup antusias, } \\
\text { karena dari sana saya bisa } \\
\text { mengetahui kehidupan } \\
\text { seseorang yang berbeda } \\
\text { gaya hidup dengan saya. } \\
\text { Rumah di perkampungan } \\
\text { tersebut yang tidak layak } \\
\text { untuk dihuni, seperti } \\
\text { kerusakan-kerusakan } \\
\text { pada rumah dan juga } \\
\text { penghawaan yang } \\
\text { kurang" }\end{array}$ & $\begin{array}{l}\text { Pengalaman } \\
\text { yang } \\
\text { berbeda }\end{array}$ & $\begin{array}{l}\text { Sempit; } \\
\text { buruknya } \\
\text { sistem } \\
\text { sirkulasi } \\
\text { udara }\end{array}$ & Antusias \\
\hline \multirow[t]{2}{*}{20.} & $\begin{array}{l}\text { "Saya merasa cukup } \\
\text { penasaran seperti apa } \\
\text { kampung nelayan, namun } \\
\text { sampai di sana ternyata } \\
\text { cuaca benar-benar terik } \\
\text { dan membuat mood saya } \\
\text { agak sedikit berubah. } \\
\text { Kemudian, sesampainya } \\
\text { di rumah Bapak Abadi, } \\
\text { saya terkejut melihat } \\
\text { rumah yang cukup kecil } \\
\text { dengan lebar hanya } \\
\text { sekitar } 3 \text { meter" }\end{array}$ & & Kecil & \\
\hline & $\begin{array}{l}\text { "Tertegun dengan } \\
\text { pandangan bahwa ada } \\
\text { rumah sekecil ini di gang } \\
\text { kecil di Surabaya, saat } \\
\text { diajak masuk ke rumah } \\
\text { yang hanya memiliki } \\
\text { luasan } 3,5 \text { x } 5 \text { dengan } 2 \\
\text { kasur, } 4 \text { lemari dan } 1 \\
\text { sekat ruangan" }\end{array}$ & & & Tertegun \\
\hline \multicolumn{5}{|l|}{21.} \\
\hline 22. & $\begin{array}{l}\text { "Banyak rumah yang } \\
\text { memiliki tempat produksi } \\
\text { makanan yang tidak } \\
\text { bersih, selain itu ada } \\
\text { tempat pembuangan } \\
\text { sampah yang jauh dari } \\
\text { kata layak dan kumuh" }\end{array}$ & & Kotor & \\
\hline & $\begin{array}{l}\text { "Saya sadar tugas saya } \\
\text { bukan hanya } \\
\text { menghantarkan perbaikan } \\
\text { rumah mereka tapi juga } \\
\text { mengerti dan memahami } \\
\text { sertar memberikan }\end{array}$ & & & Antusias \\
\hline
\end{tabular}




\begin{tabular}{|c|c|c|c|c|c|}
\hline & kepuasan untuk mereka." & & & & \\
\hline & $\begin{array}{l}\text { "Banyak hal untuk } \\
\text { menyelesaikannya. Selain } \\
\text { itu, sulit bagi saya untuk } \\
\text { membuka pembicaraan } \\
\text { dengan warga sekitar. } \\
\text { Saya takut mereka } \\
\text { merasa tersinggung atau } \\
\text { apapun itu. Saya sadar } \\
\text { perbedaan pergaulan } \\
\text { membuat topik dan cara } \\
\text { berkomunikasi berbeda } \\
\text { dan itu adalah kendala } \\
\text { untuk menggali informasi } \\
\text { yang diperlukan" }\end{array}$ & $\begin{array}{l}\text { Memahami } \\
\text { perbedaan }\end{array}$ & & $\begin{array}{l}\text { Kesulitan } \\
\text { melakukan } \\
\text { wawancara; } \\
\text { takut jika } \\
\text { merasa } \\
\text { tersinggung }\end{array}$ & \\
\hline 23. & $\begin{array}{l}\text { "Masuk ke dalam dan } \\
\text { melihat kondisi rumah, } \\
\text { saya merasa sedih. } \\
\text { Bagaimana bisa enam } \\
\text { orang tinggal di rumah } \\
\text { panas karena tidak } \\
\text { adanya penghawaan, } \\
\text { sempit dan berdesak- } \\
\text { desakan karena } \\
\text { banyaknya furniture" }\end{array}$ & & $\begin{array}{l}\text { Panas; } \\
\text { tidak ada } \\
\text { sirkulasi } \\
\text { udara }\end{array}$ & & Sedih \\
\hline 24. & $\begin{array}{l}\text { "Saya semangat bisa } \\
\text { berinteraksi langsung } \\
\text { dengan warga, satu- } \\
\text { satunya jalan untuk } \\
\text { merasakan apa yang } \\
\text { mereka rasakan, } \\
\text { berkeringat bersama } \\
\text { mereka, berbincang- } \\
\text { bincang tentang keluhan- } \\
\text { keluhan mereka sewaktu } \\
\text { tinggal di rumah itu. Saya } \\
\text { juga cukup bersyukur } \\
\text { diterima di kelas ini. } \\
\text { Kami lakukan ini dengan } \\
\text { sepenuh hati, kami } \\
\text { membawa nama Petra \& } \\
\text { HABITAT. Kami juga } \\
\text { ingin membawa } \\
\text { "happiness" untuk warga } \\
\text { yang terbantu dengan } \\
\text { KKP ini" }\end{array}$ & Bersyukur & & $\begin{array}{l}\text { Menikmati } \\
\text { prosesnya }\end{array}$ & \\
\hline & & & & & \\
\hline
\end{tabular}


Bagan 1. Korelasi antara pengalaman individu dan berbagi momen kritis

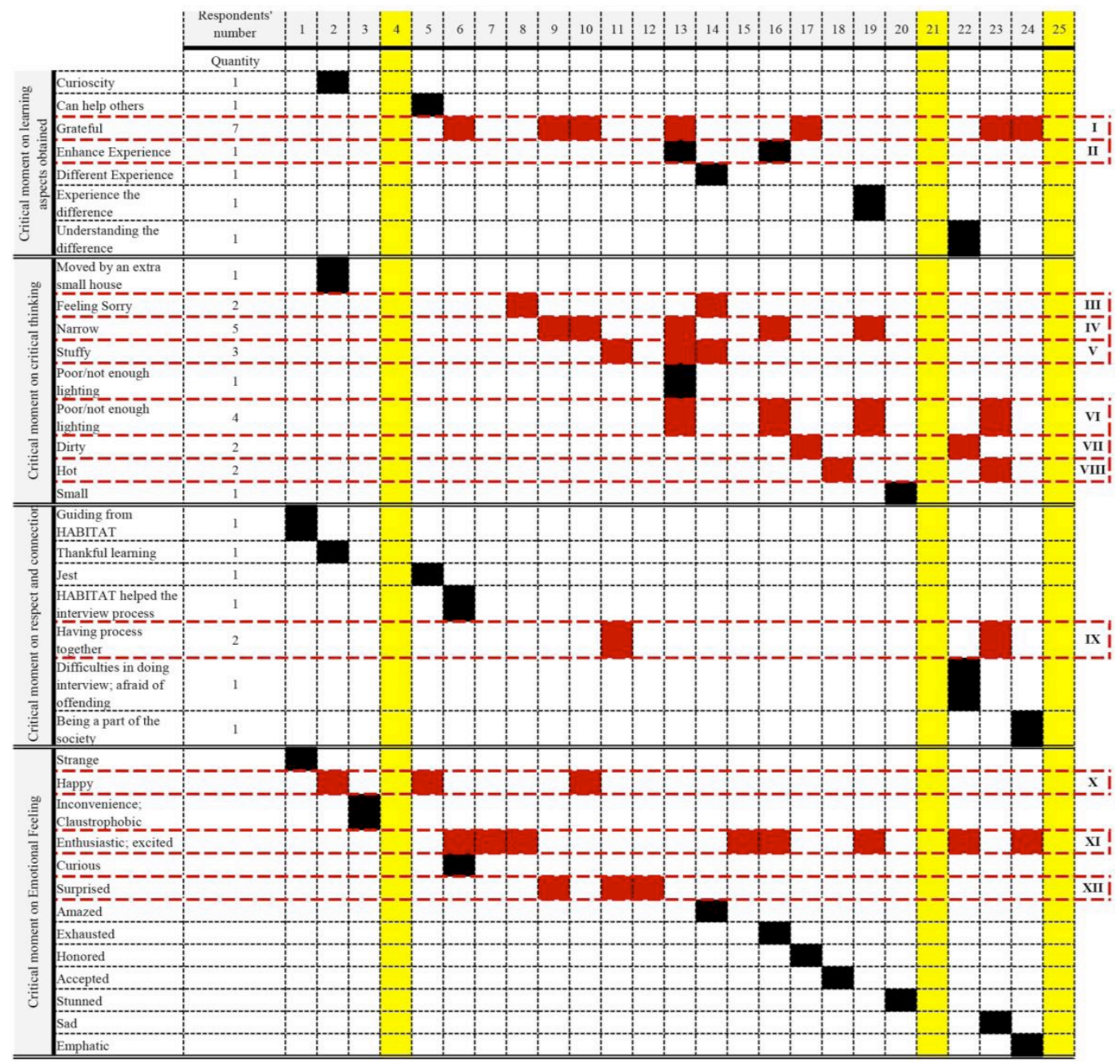

Individual Experience $\quad \square$ Shared Experiences

Source: The Author's Analysis

Sumber: Analisis penulis, 2020

\section{Kesimpulan}

Penelitian ini mengklarifikasi bahwa ada implikasi refleksi kontekstual pada momen kritis ketika pengalaman dibagikan dan menjadi pengetahuan implisit. Pengalaman yang telah dibagikan didominasi masing-masing oleh pemikiran kritis dan perasaan emosional. Kedua aspek tersebut membuktikan bahwa siswa memiliki pemikiran kritis yang tinggi terhadap situasi di lokasi kejadian. Mereka tidak hanya mengeluh tentang apa yang sudah ada disana, misalnya: situasi panas, tetapi mereka berusaha untuk mencari tahu alasan di baliknya. Selain itu, telah dinyatakan dengan jelas bahwa siswa merasa antusias dalam proyek KKN ini.

Pada aspek pembelajaran yang diperoleh, siswa menyatakan bahwa saat-saat kritis pada dasarnya muncul ketika mereka merasa bersyukur dan proyek ini meningkatkan pengalaman mereka. Selain itu, mengenai rasa hormat dan koneksi, menjalani proses bersama adalah momen kritis. Sebaliknya, menjalani proses bersama hanya dialami oleh dua dari dua puluh lima siswa dan hanya delapan dari dua 
puluh lima siswa menyatakan hubungan yang berkesan dengan masyarakat dan HABITAT sebagai mitra.

Fakta-fakta itu menjelaskan bahwa memiliki momen kritis saat melakukan proses KKN harus memiliki hubungan yang baik antara siswa dan orangorang di masyarakat. Dengan hasil itu para siswa dapat mengalami koneksi dengan orang-orang.

\section{Daftar Pustaka}

Bringle, R.G. \& Hatcher, J.A. (1999). Reflection in service-learning: Making meaning of experience. Educational Horizons, Summer 1999, 179-185.

https://digitalcommons.unomaha. edu/cgi/viewcontent.cgi?article= $1024 \&$ context $=$ slceeval

Dewey, J. (1938). Experience and education. New York: Collier Books.
Felten, P. , Gilchrist, L.Z., Darby, A. (2006). Emotion and learning: Feeling our way toward a new theory of reflection in servicelearning. Michigan Journal of Community Service Learning, Vol. 12, Spring 2006, 38-46.

http://hdl.handle.net/2027/spo.32 39521.0012 .204

Geleta, N.E. \& Gilliam, M.A. (2003). An Introduction to servicelearning. Dalam Learning to serve, serving to learn: A view from higher education. (9-13). Maryland: Salisbury University. https://files.eric.ed.gov/fulltext/E D481957.pdf

Heffernan, K. (2001). Fundamentals of service-learning course construction. USA: Campus Compact.

Kolb, D.A. (2015). Experiential Learning: Experience as the source of learning and development (Second edition). New Jersey: Pearson Education, Inc. 